\title{
The physician-scientist, the state, and the oath: thoughts for our times
}

\author{
Barry S. Coller \\ Laboratory of Blood and Vascular Biology, Rockefeller University, New York, New York, USA.
}

\begin{abstract}
Triggered by an encounter with survivors of the studies on twins conducted in Auschwitz by Joseph Mengele, who held both MD and $\mathrm{PhD}$ degrees, I offer thoughts on the extraordinary powers physician-scientists have to enhance or degrade human dignity. Biomedical science lacks intrinsic morality, but attains moral status by virtue of its purpose and the ethical framework that controls its conduct, both of which derive from the principles of medical humanism codified in the physician's oath. Physician-scientists have responsibilities to humankind that transcend the state. Careful analysis of historical examples of abuses of human rights committed in the name of medical science or the state is an important mechanism to safeguard current and future human participants.
\end{abstract}

Several years ago a patient was admitted to the Mount Sinai Medical Center in New York City with a brisk gastrointestinal hemorrhage. The physicians caring for her recommended endoscopy to assess the source of her bleeding, but she refused to undergo the procedure. When the attending gastroenterologist, Mark Babyatsky, approached the patient to discuss her decision, the patient's twin brother told him that she had terrible fears of physicians and medical interventions because Joseph Mengele performed medical procedures on her in Auschwitz as part of his twins studies. Babyatsky, who had family members perish in the Holocaust, was able to gain her confidence by his sensitivity to her fears and then performed the procedure, cauterizing a rapidly bleeding vessel in a deep ulcer. The patient subsequently recovered uneventfully.

As a physician-scientist I felt a double sense of deep visceral horror when hearing this story because Mengele not only profaned the oath he took as a physician, but also desecrated the core principles of clinical investigation. His specter is especially frightening precisely because he bore similarities to many honorable physician-scientists. In fact, he was awarded both $\mathrm{PhD}$ and medical degrees, was mentored by scientists held in high regard by their colleagues, published papers in scientific journals, and was supported by research grants from the German Research Society, even for his heinous experiments on twins in Auschwitz (1, 2).

We live at a time when scientific information, especially genetic information, is expanding dramatically, and the pressure to convert that information into improved therapies is reaching a fevered pitch. It is also a time when concerns about national security have changed our lives and laws. As a result, I feel an especial responsibility to try to understand if there are deeper lessons to be learned about the relationship among the physician, science, and governmental authority (the state) that lie hidden in the grotesque medical experiments conducted by the Nazis $(3,4)$.

\section{The power and benefits of medical science}

My motivation to become a physician-scientist derived from my realization that harnessing the power of the scientific method to prevent and alleviate suffering from disease is perhaps humankind's greatest achievement. The tangible benefits of applying scientific thought to medicine have been remarkable, and I offer just a few

Conflict of interest: The author has declared that no conflict of interest exists. Citation for this article: J. Clin. Invest. 116:2567-2570 (2006). doi:10.1172/JCI30084. notable examples to consider. As a child, I was a research subject in the 1954 Salk vaccine trial that was the first step in eradicating polio in the United States and much of the rest of the world (5). I remember firsthand how the fear of contracting polio terrorized every family in the United States at that time and the enormous sense of relief and utter joy that accompanied the announcement that the vaccine was safe and effective (5). Improvements in mortality statistics in the United States are staggering: the average lifespan increased by almost 30 years during the past century, which is greater than the increase from the beginning of recorded history until 1900 (6). And those of us who 15 years ago stood helplessly at the bedsides of patients dying of AIDS know that it was advances in the basic science of virology that led to the development of drugs that could cripple the virus - and these drugs have restored both hope and many years of life to our patients $(7,8)$.

My motivation to become a physician-scientist also grew from an appreciation that the application of scientific discovery to human health could also advance social justice, helping people throughout the world lead healthier, more productive, and more satisfying lives. In 1977 William Campbell, a scientist at Merck, recognized that the antiparasitic veterinary drug ivermectin might have human applications (9). This set in motion a series of events that culminated in the widespread use of the drug to prevent onchocerciasis (river blindness). Millions of people are now treated with ivermectin each year, an estimated 600,000 cases of blindness have been prevented, and an estimated 10 million acres of formerly evacuated arable land have been made safe again for settlement and agriculture (10).

\section{Science lacks intrinsic morality: the American eugenics movement}

As powerful as science can be as a force for good, the scientific method itself lies outside of any moral system; that is, it is intrinsically amoral. The scientific method does require an absolute commitment to the discovery of truth and it does require independent confirmation of new findings before they are incorporated into the dominant theoretical models, but these positive and self-cleansing features are not the equivalent of intrinsic morality. Scientists develop hypotheses based on the current theory of the nature of the universe and then design and conduct experiments to test these hypotheses. Although such experiments are driven by logic, the next logical experiment may be an immoral one - and nei- 


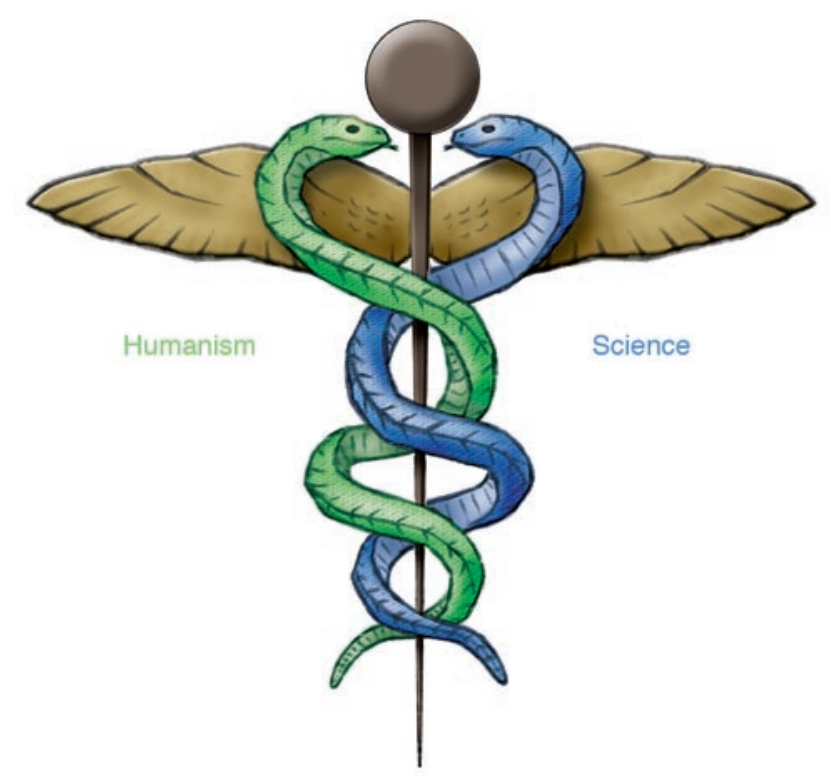

Figure 1

The intertwined relationship between humanism and science in medicine as depicted in the caduceus.

ther the pursuit of truth nor a commitment to validation through reproducibility will make that experiment moral. Science attains moral status by virtue of its purpose and the ethical framework that controls its conduct, not its intrinsic process.

The American eugenics movement at the turn of the past century was built on what was considered cutting-edge scientific knowledge from Darwinian evolution and Mendelian genetics $(1,11,12)$. Its goal was to improve the human race, and it was supported by distinguished physician-scientists and generous and respected philanthropists. To some eugenicists, the logical implication of their research was to limit the reproductive potential of those judged to be eugenically inferior. Starting with a law passed in Indiana in 1907, and expanding via similar laws in 28 other states, this reasoning ultimately led to the state-sanctioned sterilization of approximately 60,000 Americans; virtually all of these procedures were conducted with limited or no informed consent (11). The Nazis, including Hitler himself, professed great admiration for the American eugenics movement and modeled their own sterilization laws and program on those in the United States $(1,11)$.

The American eugenics movement also played a crucial role in the passage of the ignominious immigration law of 1924 (1). Its provisions for eugenic screening criteria and arbitrary immigration quotas based on the 1890 U.S. census figures were specifically designed to limit immigration of individuals from Eastern Europe because they were considered to be eugenically inferior. That law doomed thousands of Eastern Europeans trying to flee Nazi persecution by denying them the ability to emigrate to the United States. Thus, while the American eugenics movement started with a commitment to use science to improve the human condition, it rapidly degenerated into blatant racism masquerading as science and dangerously distorted public policy.

The next logical scientific experiment can be immoral, however, without being driven by ulterior motives. Many of the experiments decried by Beecher in his 1966 landmark publication (13) as being patently unethical had scientific plausibility when viewed without consideration of the protection of human research participants. Thus, if unrestricted, good science can be immoral science.

\section{The physician's oath, clinical investigation, and medical humanism}

For the physician-scientist, the moral basis of scientific experimentation derives from the physician's oath, which perhaps is best summarized as the physician's commitment to place the patient's best interests above the interests of the physician (14-17). Although the state grants the physician a license to practice medicine, the state is not a party to the oath. Rather, the physician freely and voluntarily professes the oath as a commitment to all of humankind. In fact, the oath implicitly obligates the physician to resist the actions of the state when those actions are counter to the oath or when the state requires the physician to act in ways that are counter to the oath. There is no greater good than the best interests of the individual patient who looks to his physician for comfort and healing. Neither the interests of the state nor the interests of science justify compromising that sacred trust. The Nazi Germany experience highlights the importance of this principle. In 1934, Mengele's teacher and mentor, von Verschuer, the leader of German eugenics, wrote an editorial insisting that henceforth doctors no longer owed their first duty to the patient as an individual, but rather to the state as the representative of the entire race (1).

The oath is the fullest expression of physicians' humanism, their recognition that they are united with every one of their patients through their common humanity, sharing the same hopes, the same fears - and ultimately the same fate. The Physician's Prayer attributed to Maimonides asks for divine help to ensure that the physician always sees his patient as a fellow human in pain, not a vessel of disease (18).

The relationship between medical science and medical humanism can be depicted in many ways. One way is to think of science and humanism as the two pillars of medicine, with medicine deriving support from each. A second model has science and humanism in a more complex, intertwined relationship, as the snakes that twist around the staff in the caduceus (Figure 1). But regardless of the image, the essential principle is that science should serve the cause of medical humanism rather than humans serving the cause of medical science.

What, then, constitutes medical humanism? I would suggest four core values.

First is the preciousness (or sanctity) of each human life. Many religions view human life as sacred because humans are created in God's image. The eighteenth-century Enlightenment philosopher Immanuel Kant concluded that the exercise of reason, without religious faith, would lead people to act as though the maxim of their actions were to become a universal law. This, in turn, logically leads to a recognition of the absolute value of each rational human life - the categorical imperative - and by modern extension, the absolute value of all life. Closely aligned with the concept of the preciousness of human life are other extensions of Kant's ideas, the concepts of human dignity and that human life is an end in and of itself. Thus, human life should never be sacrificed to achieve an end - even when the state has an interest in achieving that end, even at a time of war, even when an important medical theory would dramatically improve our understanding of disease and pave the way to important new therapies.

The second value is respect for human dignity. Respecting and protecting patients' dignity and sense of self-respect, especially 
when illness or other circumstances makes them particularly vulnerable and powerless, is true compassion. The master clinician not only elicits the elusive, but crucial, fact from the medical history and identifies the subtle physical finding that illustrates the pathologic mechanism, but also makes sure that the patient's privacy and modesty are protected in the process. Saving a human life, no matter how brilliantly or heroically, falls short of fulfilling the requirements of medical humanism unless it is coupled with demonstrating respect for the survivor's dignity.

The third core value of humanism is the celebration of human diversity. We are all enriched by exchanging ideas with those who have had different life experiences and as a result have different perspectives, talents, and interests. In addition to the cultural benefits of human diversity, however, there are compelling biologic reasons to celebrate diversity. We now recognize that humans are genetically very homogeneous, with variations occurring in fewer than one out of a thousand nucleotides, and with fewer than one percent of these variations affecting protein structure (19). Although it may not be obvious, this lack of genetic diversity represents a serious vulnerability, especially in light of the increasing threat of pandemic infections (20). A silent amino acid substitution in a receptor today may be the key to the survival of our species tomorrow (21). Nothing could be riskier than all of us having exactly the same genes, even if each gene is perfect by today's standards. Instead of being a master race, we would more likely be a dreadfully boring biological sitting duck, obsessed with avoiding our own extinction.

Finally, the fourth core value of medical humanism is a sympathetic appreciation of the complexity of the human condition - how difficult it is for anyone to meet all of society's idealized expectations regarding individual and interpersonal behaviors, and how history and circumstances have conspired to make it especially difficult for some.

\section{Medical humanism and the origin of human rights}

Although the concepts of medical humanism may seem axiomatic, they grow from more fundamental concepts of human rights and even more fundamental concepts of right and wrong. From a Darwinian perspective, until humans appeared on earth, evolution proceeded independent of moral judgment. Humans, however, not only have the ability to communicate with each other through language, but also have the ability to feel the complex emotions that we generally term empathy and sympathy (22-24). These emotions are important components of the belief systems that inform our moral decision making and that are conveyed to succeeding generations through verbal and nonverbal communication. A belief system is so fundamental to our psychic structure that it exists at a level below day-to-day thoughts. Like a computer's operating system, it not only defines the kind of mental operations we can perform, but also defines and limits the type of information we are able to perceive, organize, and analyze. As such, it imperceptibly colors all of our perceptions - and conditions our sense of right and wrong. A defining element in a person's belief system is how far the emotions of empathy and sympathy radiate out from the individual. For some people, these emotions don't extend out at all; for others, they only extend to their families or to people of the same religion or race; and for others, they stop at the borders of their country. Nazi propaganda was specifically designed to limit the German people's feelings of sympathy and empathy for victims of their atrocities by depicting them as not worthy of these emotions because they were inferior beings who were a threat to the Aryan race and Germany (25). The physician's professional commitment under the oath radiates outward to all of humankind, thus superimposing a physician-specific belief system on top of whatever belief system the physician holds. The oath not only conditions physicians' thinking and unites them in a common cause, but also generates special responsibilities to provide moral leadership when individuals seek to narrow the radiation of the society's empathy and sympathy.

Belief systems themselves are in evolutionary competition, and they evolve or are supplanted over time. Human sacrifice, the divine right of kings, and slavery were all once central elements in dominant belief systems, as were the pernicious pseudoscientific notions of racial purity that dominated Nazi thought. We dismiss all of these now because we have very different belief systems, which makes it especially important for us to try to understand how people at other times could have adopted those belief systems.

More pointedly, how does one judge whether a belief system is immoral, especially if it is the currently dominant one? Can one determine absolute right and wrong? In a recent book, Alan Dershowitz asked the related question that has been the subject of the thoughts and writings of political philosophers for centuries: "Where do human rights come from?" (26). He considered a number of potential sources. One, embodied in our own Declaration of Independence, is that they derive from God, that all people are "endowed by their Creator with certain unalienable Rights," among which are life, liberty, and the pursuit of happiness. As powerful and as important as that idea is, it lacks universality because of differences among groups in their beliefs about the nature of God and, indeed, whether God even exists. A second possible source of human rights is the law itself, duly enacted by a sovereign government. This also falls short of setting a universal standard because we know full well that even duly elected governments may use the law not as a means of protecting individual rights, but as a means of denying them. The Fugitive Slave Act of 1850 in the United States (27) and the Nuremberg racial laws in Nazi Germany are painful reminders of this fact (1). Dershowitz also found nothing compelling in the arguments put forward to suggest that rights derive from the laws of nature or from logic. He concluded that rights legitimately come from humans closely examining their collective experience with injustices and then constructing and entrenching those human rights that would have prevented them. Since there is far greater consensus about what constitutes gross injustice than what constitutes perfect justice, it is easier to establish universal moral imperatives from these painful experiences.

While this concept of deriving rights from the analysis of wrongs has its own limitations, especially since one's belief system will undoubtedly affect what one judges to be gross injustices, it does provide an operational guide to both reflection and action. Thus, it is our duty to reflect on the great injustices in recorded history, to consider carefully when possible the words of eyewitnesses, and to then try to establish standards of human rights to prevent future crimes against humanity. The Nuremberg Code of 1947, which is considered by many to be the most important document in the history of medical research, was formulated by American judges after the trials of Nazi physicians who conducted heinous experiments on humans in the concentration camps (3). Moreover, reflections on the medical atrocities committed during the war acted as a stimulus for American medical schools to include a public declaration of an oath at the time of graduation (14). Physicians in general, by virtue of their role in society and their oath, and physician-scientists in particular, by virtue of their extraordinary power to advance or degrade human dignity, bear especial responsibility to learn from history and develop safeguards against future abuses and injustices. 
Active participation in this process is also the most meaningful way to honor the sacrifice of all those who have suffered and all those who have perished as a result of inhuman actions.

\section{Acknowledgments}

I want to thank Mark Babyatsky for stimulating my interest in this topic and for his encouragement and helpful suggestions; Andrew
Leavitt, Roger Berkowitz, and Jonathan Weiner for constructive criticisms; and Suzanne Rivera for outstanding secretarial assistance.

Address correspondence to: Barry S. Coller, Laboratory of Blood and Vascular Biology, Rockefeller University, 1230 York Avenue, New York, New York 10021, USA. Phone: (212) 327-7490; Fax: (212) 327-7493; E-mail: collerb@rockefeller.edu.
1. Black, E. 2003. War against the weak: eugenics and America's campaign to create a master race. Four Walls Eight Windows. New York, New York, USA. 550 pp.

2. Muller-Hill, B. 2001. Genetics of susceptibility to tuberculosis: Mengele's experiments in Auschwitz. Nat. Rev. Genet. 2:631-634.

3. Shuster, E. 1997. Fifty years later: the significance of the Nuremberg Code. N. Engl. J. Med. 337:1436-1440.

4. Lifton, R. 1986. The Nazi doctors: medical killing and the psychology of genocide. Basic Books. New York, New York, USA. 561 pp.

5. Mitka, M. 2005. Happy 50th birthday, Salk vaccine. JAMA. 293:1581-1583.

6. National Center for Health Statistics. 2006. Trends in health and aging. United States Center for Disease Control and Prevention. www.cdc.gov/nchs/ agingact.htm.

7. Fauci, A.S. 2003. HIV and AIDS: 20 years of science. Nat. Med. 9:839-843.

8. Pomerantz, R.J., and Horn, D.L. 2003. Twenty years of therapy for HIV-1 infection. Nat. Med. 9:867-873.

9. Collins, K. 2004. Profitable gifts: a history of the Merck Mectizan donation program and its implications for international health. Perspect. Biol. Med 47:100-109.
10. 2006. Global partnership to eliminate riverblindness. The World Bank Group. www.worldbank. org/afr/gper.

11. Kühl, S. 1994. The Nazi connection: eugenics, American racism, and German national socialism. Oxford University Press. New York, New York, USA. 166 pp.

12. Sofair, A.N., and Kaldjian, L.C. 2000. Eugenic sterilization and a qualified Nazi analogy: the United States and Germany, 1930-1945. Ann. Intern. Med. 132:312-319.

13. Beecher, H.K. 1966. Ethics and clinical research. N. Engl. J. Med. 274:1354-1360.

14. Smith, D.C. 1996. The Hippocratic Oath and modern medicine. J. Hist. Med. Allied Sci. 51:484-500.

15. Orr, R.D., Pang, N., Pellegrino, E.D., and Siegler, M. 1997. Use of the Hippocratic Oath: a review of twentieth century practice and a content analysis of oaths administered in medical schools in the U.S. and Canada in 1993. J. Clin. Ethics. 8:377-388.

16. Hurwitz, B., and Richardson, R. 1997. Swearing to care: the resurgence in medical oaths. BMJ. 315:1671-1674.

17. Westerveld, H.E., et al. 2005. Dutch medical oath. Neth. J. Med. 63:368-372.

18. [Anonymous]. 2006. Definition of Maimonides' prayer. http://www.medterms.com/script/main/ art.asp?articlekey $=4247$.

19. Venter, J.C., et al. 2001. The sequence of the human genome. Science. 291:1304-1351.

20. Liu, J.P. 2006. Avian influenza - a pandemic waiting to happen? J. Microbiol. Immunol. Infect. 39:4-10.

21. Galvani, A.P., and Novembre, J. 2005. The evolutionary history of the CCR5-Delta32 HIV-resistance mutation. Microbes Infect. 7:302-309.

22. Blair, R.J. 2005. Responding to the emotions of others: dissociating forms of empathy through the study of typical and psychiatric populations. Conscious. Cogn. 14:698-718.

23. Saxe, R. 2006. Uniquely human social cognition. Curr. Opin. Neurobiol. 16:235-239.

24. Preston, S.D., and de Waal, F.B. 2002. Empathy: its ultimate and proximate bases. Behav. Brain Sci. 25:1-20.

25. Herf, J. 2006. The Jewish enemy: Nazi propaganda during World War II and the Holocaust. Belknap Press. Cambridge, Massachusetts, USA. 390 pp.

26. Dershowitz, A.M. 2004. Rights from wrongs: the origins of human rights in the experiences of injustice. Basic Books. New York, New York, USA. 261 pp.

27. Cochran, W.C. 2004. The Western Reserve and the Fugitive Slave law; a prelude to the Civil War. Kessinger Publishing. Cleveland, Ohio, USA. 240 pp. 